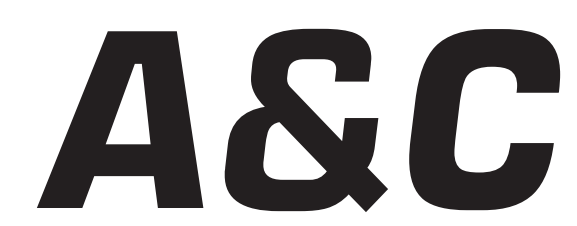

Revista de Direito Administrativo \& Constitucional

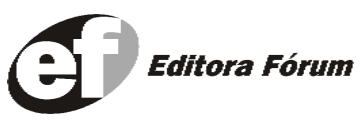

A\&C R. de Dir. Administrativo e Constitucional, Belo Horizonte, ano 5, n.19, p. 1-254, jan./mar. 2005 


\section{A\&C REVISTA DE DIREITO ADMINISTRATIVO E CONSTITUCIONAL}

\section{IPDA}

Instituto Paranaense

de Direito Administrativo

Direção Geral

Romeu Felipe Bacellar Filho

Direção Editorial

Paulo Roberto Ferreira Motta

Direção Executiva

Emerson Gabardo

Conselho de Redação

Edgar Chiuratto Guimarães

Adriana da Costa Ricardo Schier

Célio Heitor Guimarães

Conselho Editorial

Adilson Abreu Dallari

Alice Gonzáles Borges

Carlos Ari Sundfeld

Carlos Ayres Britto

Carlos Delpiazzo

Cármen Lúcia Antunes Rocha

Celso Antônio Bandeira de Mello

Clèmerson Merlin Clève

Clóvis Beznos

Enrique Silva Cimma

Eros Roberto Grau

Fabrício Motta

Guilhermo Andrés Muñoz (in memoriam)

Jaime Rodríguez-Arana Muñoz

Jorge Luís Salomoni
José Carlos Abraão
José Eduardo Martins Cardoso

José Luís Said

José Mario Serrate Paz

Juan Pablo Cajarville Peruffo

Juarez Freitas

Julio Rodolfo Comadira

Luís Enrique Chase Plate

Lúcia Valle Figueiredo

Manoel de Oliveira Franco Sobrinho

(in memoriam)

Marçal Justen Filho

Marcelo Figueiredo

Márcio Cammarosano

Maria Cristina Cesar de Oliveira
Nelson Figueiredo

Odilon Borges Junior

Pascual Caiella

Paulo Eduardo Garrido Modesto

Paulo Henrique Blasi

Paulo Neves de Carvalho (in memoriam)

Paulo Ricardo Schier

Pedro Paulo de Almeida Dutra

Regina Maria Macedo Nery Ferrari

Rogério Gesta Leal

Rolando Pantoja Bauzá

Sérgio Ferraz

Valmir Pontes Filho

Yara Stropa

Weida Zancaner

\footnotetext{
A246 A\&C Revista de Direito Administrativo e Constitucional. ano 3, n. 11, jan./mar. 2003. Belo Horizonte: Fórum, 2003.

Trimestral

ano 1, n.1, 1999 até ano 2, n.10, 2002 publicada pela Editora Juruá em Curitiba

ISSN: 1516-3210

1. Direito Administrativo. 2. Direito Constitucional. I. Fórum.
}

CDD: 342 CDU: 33.342

(c) Editora Fórum Ltda. 2005

Todos os direitos reservados. É proibida a reprodução total ou parcial, de qualquer forma ou por qualquer meio eletrônico ou mecânico, inclusive através de processos xerográficos, de fotocópias ou de gravação, sem permissão por escrito do possuidor dos direitos de cópias (Lei $n^{\circ}$ 9.610, de 19.02.1998).

Editora Fórum Ltda

Av. Afonso Pena, 2770 - 15\%16ªndar - Funcionários

CEP 30130-007 - Belo Horizonte/MG - Brasil

Tel.: 08007043737

Internet: www.editoraforum.com.br

e-mail: editoraforum@editoraforum.com.br
Editor responsável: Luís Cláudio Rodrigues Ferreira Projeto gráfico e diagramação: Luis Alberto Pimenta Revisora: Olga M. A. Sousa

Pesquisa jurídica: Fátima Ribeiro - OAB/MG 74868

Bibliotecária: Nilcéia Lage de Medeiros

CRB 1545/MG 6a região

Os conceitos e opiniões expressas nos trabalhos assinados são de responsabilidade exclusiva de seus autores.

Impressa no Brasil / Printed in Brazil

Distribuída em todo Território Nacional 


\title{
O Conceito Atual de Serviço Público na República Argentina
}

\author{
Jorge Luis Salomoni \\ Presidente de la Asociación Argentina de Derecho Administrativo. Profesor Titular de Derecho \\ Administrativo de la Universidad de Belgrano. Director del Posgrado en Derecho Administrativo \\ de la Universidades de Belgrano y de Roma "La Sapienza". Profesor Adjunto Regular de Derecho \\ Administrativo de la Universidades de Buenos Aires y Nacional de La Plata. Director del Instituto de \\ Derecho Administrativo de la Universidad Notarial Argentina
}

Sumário: 1 Breve menção da demarcação genérica de desenvolvimento do conceito serviço público - 2 Breve desenvolvimento histórico do conceito de serviço público na República Argentina - 3 Conceito atual de Serviço Público - 4 Conclusão

O conceito jurídico de serviço público, fundamentalmente na Europa continental, passou por diversas formulações e reformulações ao longo da história do direito administrativo em uma tentativa de determinar a atividade que abrange. Algumas vezes, a ênfase estava no sujeito prestador, em outras, na natureza, abrangência e conteúdo da atividade. Em alguns casos, a formulação tentou enlaçar todas essas preocupações, ou substituí-las por outras. ${ }^{1}$

Dessa forma, e somente como exemplo sem a pretensão de abarcar o desenvolvimento das diversas concepções elaboradas, por um lado, o serviço público serviu para estabelecer a idéia central para a construção do direito administrativo, fundamentalmente na França através do insigne mestre Duguit, em contraposição à puissance publique de Hauriou. ${ }^{2}$ Foram construídas as teorias subjetiva e objetiva do serviço público, esta última de origem italiana, e cujo autor, como se sabe, foi Umberto Pototschnig. A tese subjetiva exigiu a presença da administração pública como titular e gestor da atividade para qualificá-la como serviço público. A tese objetiva, por sua vez e em outra etapa histórica, pretendeu estabelecer na natureza da atividade, o dado da disciplina jurídica à que estava submetida, prescindindo do sujeito titular.

\footnotetext{
1 Para uma evolução do conceito de serviço público, ver: MIGUEZ MACHO, Luis. Los Serviços Públicos y el Régimen Jurídico de los Usuarios. Barcelona: Cedecs Editorial, 1999, capítulo II.

2 Para uma ampliação, ver: GARRIDO FALLA, Fernando. ¿Crisis de la Noción del servicio público?. In: VVAA. Estudios de Derecho Público Económico. Livro Homenagem ao Prof. D. Sebastián Martín-Retortillo. Civitas, 2003, p. 441 et seq. Também em: GARCÍA DE ENTERRRÍA, Eduardo; Fernández, Tomás-Ramón. Curso de Derecho Administrativo. Madri: Civitas, 2002, t. I, p. 51 et seq. Ver: FERNÁNDEZ, Tomás-Ramón. Del Servicio Público a la Liberalización desde 1950 hasta Hoy. In: Panorama del Derecho Administrativo al Comienzo de su Tercera Centuria. Com nota introdutória de Julio Rodolfo Comadira. Buenos Aires: La Ley, 2002, p. 45 et seq.
} 
Por sua importância e influência na Argentina cabe mencionar a tese denominada formalista, por meio da qual Gastón Jèze, tentou construir o conceito conferindo um papel relevante ao procedimento organizativo do serviço público e ao regime jurídico especial que o regia. ${ }^{3}$

Tais formulações teóricas causaram forte impacto não só em nosso país como também em toda a América Latina, onde o serviço público foi tratado com base nas diversas doutrinas formuladas principalmente na França e na Itália, e também nas adaptações e modulações próprias da doutrina espanhola.

Do meu ponto de vista, o estudo do serviço público na República Argentina omitiu, em primeiro lugar, a consideração dos antecedentes normativos e de jurisprudência de nosso direito pátrio - 1810/1852 — e dos primórdios da Organização Nacional — 1853/1890 —, que estabeleceram um conceito de serviço público amplíssimo, como se verá, que consistia na identificação com a atividade total e permanente do Estado, especialmente no que se referia ao Poder Executivo. Em segundo lugar, e quiçá, como conseqüência irremediável dessa omissão, faltou uma concepção integral que colocasse a categoria jurídica de serviço público dentro do sistema de potestades estatais e de direitos dos particulares, emergente de nosso ordenamento jurídico positivo. $\mathrm{O}$ ordenamento vigente foi substituído, na maioria das elaborações teóricas, pelas teorias européias que faziam referência a outros ordenamentos e a outras configurações estatais.

Neste trabalho tentarei reconstruir o conceito normativo histórico de serviço público produzido em nosso país, estabelecendo o contexto genérico de desenvolvimento do conceito, conforme minha opinião, e chegando a uma definição que surgirá do ordenamento jurídico vigente e da jurisprudência inveterada da Corte Suprema de Justiça da Nação.

Na tentativa de construir o conceito atual de serviço público parti de duas premissas. A primeira consiste em que, apesar de concordar com o fato de ser difícil estabelecer categorias universais para os distintos contratos ou permissões administrativas e, dentro deles para a diversa gama de técnicas estabelecidas para a privatização de serviços públicos em nosso país, pois “...é preciso procurar o regime concreto no conjunto normativo de cada contrato determinado e individualizado...", ${ }_{4}^{4}$ considero possível tentar

\footnotetext{
3 JÉZE, Gastón. Principios Generales del Derecho Administrativo. Buenos Aires: Depalma, 1949, t. II (1), Capítulo I.

4 GORDILLO, Agustín. Tratado de Derecho Administrativo. 3. ed. Ediciones Macchi, 1995, t. 1, cap. XI, p. 21.
}

A \& C R. de Dir. Administrativo e Constitucional, Belo Horizonte, ano 5, n. 19, p. 11-34, jan./mar. 2005 
uma racionalização ${ }^{5}$ e generalização de seus principais aspectos, que nos conduzam a um conceito unitário da instituição analisada. Em minha opinião, isso implica que as técnicas utilizadas para a prestação de serviços não podem alterar o conceito de serviço público.

A segunda premissa é que, tanto a lei geral nacional de Reforma do Estado $\mathrm{n}^{\circ}$ 23.696, que autorizou o processo de delegação de prestação de serviços públicos a setores privados, quanto as leis nacionais particulares que estabeleceram os marcos regulatórios de eletricidade $n^{\circ} 24.065$ e de gás $\mathrm{n}^{\mathrm{o}} 24.076$ e os diversos regulamentos ditados para distintos serviços, não alteraram substancialmente a rica concepção histórica sobre o serviço público que se desenvolveu em nosso país, no âmbito normativo, jurisprudencial e doutrinário. Portanto, sustentarei que a jurisprudência da Corte Suprema de Justiça da Nação, por meio da doutrina de suas sentenças, pode coadjuvar, juntamente com as normas constitucionais, legais e regulamentares vigentes, a integrar o conceito buscado.

\section{Breve menção da demarcação genérica de desenvolvimento do conceito serviço público}

Como afirmei anteriormente, ${ }^{6}$ o serviço público envolve, pelo menos, quatro âmbitos que se inter-relacionam e procuram configurar o limite externo ou contexto de desenvolvimento do conceito:

a) uma teoria do Estado, que envolve por sua vez:

i.- Uma teoria do poder, no que se refere a suas formas e fundamento;

ii.- Os elementos constitutivos do Estado;

iii.- As formas do Estado, no que se refere à sua extensão (Estado máximo e Estado mínimo); e

iv.- A continuidade do Estado e sua configuração futura;

b) com relação à forma adotada pelo Estado, a indagação de seu grau de intervenção na economia e, em conseqüência, o grau de autonomia da sociedade com relação ao Estado.

Sob esta perspectiva, pode-se considerar a intervenção estatal através de alguns dos seguintes instrumentos:

\footnotetext{
5 "Os princípios são mecanismos de transmissão de probabilidade ou apoio, que vão de dados ou casos, através dos princípios, a juízos e predições sobre novas observações ou casos cujo status resulta, por outro lado, desconhecido ou menos provável... Os princípios ou teorias gerais têm, pois, uma função intelectual geral: a justificação perante outros. A justificação mediante princípios gerais resulta convincente de duas maneiras: pelo atrativo aparente dos princípios e por recrutar outros casos já aceitos em apoio de uma posição proposta para o caso presente". (NOZIK, Robert. La Naturaleza de la Racionalidade. Barcelona: Paidós, 1995, p. 23-24).

6 Para o que vem a seguir, ver: SALOMONI, Jorge Luis. Teoría General de los Servicios Públicos. Buenos Aires: Ad-Hoc, 1999, p. 325-327.
}

A \& C R. de Dir. Administrativo e Constitucional, Belo Horizonte, ano 5, n. 19, p. 11-34, jan./mar. 2005 
i.- Técnica de sujeição dos fatores produtivos privados à planificação estatal;

ii.- Técnica de regulação de mercados;

iii.- Técnica de distribuição de bens e serviços.

c) como técnica de garantia dos Direitos Humanos, que poderia sintetizar-se em:

i.- Técnica de igualação do usufruto dos bens materiais e culturais produzidos em uma sociedade e para todos os indivíduos que a compõem.

ii.- Técnica de igualdade de tratamento jurídico e político.

iii.- Técnica de integração social.

d) e, finalmente, como conceito técnico jurídico administrativo em que se descreve a prestação de uma atividade que tem em vista a satisfação de necessidades públicas.

Esta demarcação conceitual facilitará, como se verá adiante, a conformação do conceito de serviço público que surge de nosso sistema constitucional, plano normativo, por outra parte, em que se plasmam os quatro âmbitos enunciados.

\section{Breve desenvolvimento histórico do conceito de serviço público na República Argentina}

Tanto os antecedentes pátrios quanto as primeiras legislações da etapa da Organização Nacional sobre determinadas atividades concedidas ou delegadas a particulares, denominadas, nessas mesmas normas, serviços públicos, configuraram um regime jurídico substantivo e peculiar, diferente do regime do direito privado. ${ }^{7}$

Recentemente, e como produto de um importantíssimo trabalho de pesquisa, González Moras ${ }^{8}$ afirmou que: "o aparecimento, em nosso país, do

\footnotetext{
Diferentemente da experiência argentina: "(Na Espanha) O serviço público serve exclusivamente de critério para a separação jurisdicional: são contratos administrativos todos os que tiverem por objeto as obras e serviços públicos. Embora a jurisprudência algumas vezes confunda a causa de utilidade ou necessidade pública com o objeto do contrato (obras ou serviços públicos), normalmente costuma separar ambos os elementos. O serviço público surge, assim, como um critério jurisdicional, sem adquirir, no momento de seu nascimento, a configuração de uma categoria jurídica substantiva. Nesse sentido, afirmava Santamaría de Paredes que ' a jurisprudência, ao estabelecer o princípio da jurisdição contencioso-administrativa, não pode reconhecer mais do que aqueles contratos celebrados pela Administração para uma obra ou serviço público, vindo a declarar contratos civis todos os demais da Administração que não são para obras ou serviços públicos'. Como postulava Fernández de Velazco, também nessa mesma direção,

nosso Direito positivo não se encontra um conceito próprio da noção de serviço público'". (VILLAR EZCURRA, José Luis. Servicio Público y Técnicas de Conexión. Madri: Centro de Estudios Constitucionales, 1980, p. 43-44).

\& GONZÁlEZ MORAS, Juan M. O Conceito de Serviço Público. In: JORNADAS NACIONAIS DE DIREITO
}

A \& C R. de Dir. Administrativo e Constitucional, Belo Horizonte, ano 5, n. 19, p. 11-34, jan./mar. 2005 
conceito normativo de serviço público em sentido amplo deve ser buscado no momento da consolidação do chamado "direito pátrio", de 1810 a 1853, tendo sido utilizado, concretamente, pelas Assembléias Constituintes de 1813 e $1826 " .9$

Fica claro que o conceito normativo de serviço público identificouse genericamente, nessa etapa histórica, tanto com a atividade normal do Estado quanto com a atividade total e permanente da Administração Pública, estabelecido em normas da mais alta hierarquia. Algo similar ocorreu na Espanha sem, no entanto, a intensidade conceitual e a relevância normativa que adquiriu na Argentina. ${ }^{10}$

Como uma continuidade histórica, no momento do início da

9 De fato, e em primeiro lugar, temos o Decreto da Soberana Assembléia Geral Constituinte, de 6 de fevereiro de 1813, pelo qual se dispôs que: "..o espanhol europeu empregado que solicitar ser cidadão do estado, poderá gozar deste caráter sob as seguintes condições. (...) Primeira. Deve comprovar de maneira indiscutível não só uma decidida adesão à sagrada causa da liberdade da América desde a gloriosa revolução destas províncias, como também deve ter prestado esforços e serviços públicos incontestáveis em seu fomento e defesa..." Da mesma maneira, o Decreto do Congresso Geral Constituinte que funcionava como legislatura da província de Buenos Aires, que foi proposto e cuja discussão teve início na sessão secreta de 25 de novembro de 1825, e que foi, posteriormente, aprovado, dispôs: "ARTIGO 1.- Autoriza-se o governo encarregado do Executivo nacional a buscar e admitir temporariamente um Chefe que forme e dirija a esquadra nacional (...) Art. 5.- Se o Chefe vier de outra nação com autorização de seu governo, e morrer em ação de guerra, sua mulher e filhos legítimos gozarão de meio soldo por via de pensão, a primeira para toda a vida, se não tomar novo estado; e nesse caso, ou de falecimento, a pensão passará aos filhos: com relação aos filhos, as mulheres a desfrutarão até que se casem, e os varões até a idade de vinte e um anos, se antes não tomarem carreira no serviço público." Na sessão de 24 de abril de 1826, ao debater-se no próprio Congresso Geral Constituinte, a "Adição ao orçamento dos gastos de polícia para o ano de 1826", da província de Buenos Aires, o Ministro de Governo expressava que: "...farei ao Congresso uma observação que é importante para cobrir a responsabilidade do Governo de hoje em diante. O Governo até agora não está em regra, nem pode estar: ele parte do princípio de que não pode ser nossa organização regular enquanto os gastos que fizer não forem decretados por lei. Começou a desempenhar as delicadas funções de um governo geral de todo o território da República com um orçamento de gastos tão diminuto que está quase limitado aos gastos do departamento de guerra e de marinha, pois nos departamentos de governo, fazenda e relações exteriores é muito pouco o que existe, porque tudo era desempenhado provisoriamente pelo Governo da província de Buenos Aires, com as dotações a ele destinadas, e considerando as funções que exercia. Desde que foi estabelecido o Poder Executivo permanente foi preciso que sua esfera ação se expandisse muito além do que poderia abarcar o Governo provisório: por conseguinte, quando foi necessário realizar maiores gastos, o governo não considerou conveniente pedir uma autorização para cada um, porque teria que manter o Congresso ocupado com cada um deles. O Governo os decretou de acordo com as necessidades do serviço público; e só poderá fazê-lo novamente depois que tomar conhecimento exato de tudo, e que houver destinado o que é indispensável para o serviço geral; ele então apresentará o orçamento de gastos necessário..." Da mesma maneira, no próprio Congresso Geral Constituinte, ao serem discutidos os gastos "... para o serviço da casa e da Secretaria do Congresso Geral no presente ano de 1826...", expressava-se que: "...parece conveniente observar quanto à indicação feita de valer-se para ordenança de um ou de dois soldados de cavalaria, que o Governo considerou o prejuízo resultante de valer-se da tropa para esses destinos, porque os soldados abandonam-se e se sentem desmoralizados, e por isso manda por ordem geral, que todos os ordenanças de empregos civis sejam ordenanças assalariados e não militares. Por essa razão nos tribunais de primeira instância e nos tribunais da Câmara os ordenanças têm 200 pesos, sem manter cavalo, pois thes dão um do serviço público que, de modo geral, é ruim e não pode fazer quase nada..."

${ }^{10}$ A doutrina espanhola disse sobre esse particular, que: "É preciso lembrar também que outra das conquistas desta nova geração de administrativistas (refere-se aos emergentes da década de 50) foi a realização de uma série de pesquisas sobre as origens do serviço público, que trouxeram à tona o caráter autônomo de seu nascimento como instituição jurídica em nossa pátria. Sendo assim, e diferentemente de tantas outras instituições do Direito administrativo espanhol, esta técnica não teria sido importada da França, embora em um princípio nossa doutrina administrativista, como já se disse, não tenha elaborado uma teoria jurídica própria do serviço público, mas tenha acolhido a elaborada no país vizinho". (MIGUEZ MACHO, Luis, op. cit., "Los Servicios Públicos...", p. 73-74. 
Organização Nacional aprofunda-se o âmbito de aplicação do conceito, precisando suas peculiaridades e especificidades.

Como se sabe, no momento da sanção da Constituição Nacional de 1853, existiam duas ordens jurídicas no território da atual República Argentina. ${ }^{11}$ Por um lado, a Confederação Argentina, com sede na cidade de Paraná, e por outro lado, a Província e Estado de Buenos Aires, com sede no porto de Buenos Aires, que havia se separado da mencionada Confederação.

Coincidentemente, tanto uma quanto a outra, sancionaram contemporaneamente, regras jurídicas que restabeleceram o mencionado conceito normativo de serviço público.

A Confederação Argentina sancionou, em 9 de dezembro de 1853, o Estatuto de Fazenda e Crédito, cujo Título IV, “Crédito Público”, Capítulo I, Artigo 3, prescreveu que:

Toda soma que o Congresso Federal Argentino dispuser antecipar ao Poder Executivo nacional, para o giro de banco, construção de obras públicas ou para o serviço público, seja em fundos públicos ou em dinheiro circulante, como moeda corrente, será inscrita no livro de crédito público e firmado por todos os membros do Congresso presentes à sessão. ${ }^{12}$

A norma pré-transcrita constituiu a primeira legislação argentina posterior à sanção da Constituição em que se volta a utilizar o conceito serviço público, e a garantia de sua constituição e prestação é atribuída especificamente, como incumbência ou potestade, ao próprio Estado.

Por sua vez, a Lei $n^{\circ} 24$, de 27 de junho de $1855,{ }^{13}$ pela qual o Poder Executivo da Confederação foi autorizado “...para conceder o privilégio da construção de uma ferrovia, desde um ponto de Paraná até a cidade de Córdoba, sob condições similares, o máximo possível, aos termos do acordo de dois de abril do presente ano". ${ }^{14}$ Dita lei foi acompanhada de umas "bases do serviço", que operaram como regulamento do mesmo, e de onde surgem os primeiros traços que podem ser atribuídos ao serviço público, estabelecendo, no que aqui interessa:

i.- O caráter de regularidade do serviço, ao sancionar as bases jurídicas e técnicas às quais deveria sujeitar-se.

ii.- A reversão ao Estado, no final da concessão, dos bens destinados ao serviço, como "os terrenos do caminho e toda a parte imóvel...". ${ }^{15}$

\footnotetext{
${ }^{11} \mathrm{O}$ desenvolvimento a seguir baseia-se em: SALOMONI, Jorge Luis, op. cit., "Teoria Geral...", p. 136 et seq.

12 "Anais de Legislación Argentina" (Adla,) 1852-1880, p. 96 et seq.

${ }^{13}$ Coleção Congresso Federal de Paraná - Leis sancionadas em 1855, p. 191-192.

${ }^{14}$ Artigo 1 da lei 24.
}

A \& C R. de Dir. Administrativo e Constitucional, Belo Horizonte, ano 5, n. 19, p. 11-34, jan./mar. 2005 
iii.- O valor residual dos bens, ao prescrever que "as carruagens e todos os bens imóveis serão, chegado o momento, taxados em seu justo valor e pagos à empresa pelo Governo, a quem passarão a pertencer". ${ }^{16}$ iv.- O caráter público dos bens destinados ao serviço, ao estabelecer que, "a ferrovia e todas as suas dependências, serão consideradas como propriedade particular; e gozarão da especial proteção do Governo Nacional e local, inclusive com força armada, se for solicitada" ${ }^{17}$

Entre outras disposições.

É evidente que o conceito de serviço público não é mencionado da mesma forma que na lei do Estado e Província de Buenos Aires, como se verá abaixo, pois esse conceito estava contido no pré-transcrito Estatuto de Fazenda e Crédito da Confederação Argentina.

Por outra parte, encontra-se o Decreto Legislativo de 9 de janeiro de $1854^{18}$ que autorizou o Poder Executivo do Estado e Província de Buenos Aires, a conceder licença para a construção e exploração, por particulares, de uma ferrovia no Oeste e, no que aqui interessa, para a demonstração da originalidade da conformação do direito público nacional, sujeita dita concessão, às seguintes bases:

i.- Estabeleceu-se o caráter de regularidade de prestação do serviço público ao sujeitar tal exploração, por parte de particulares, às bases jurídicas ditadas a tal efeito na norma em análise. Cabe destacar que, posteriormente, todas as normas de concessão para a exploração de ferrovias fizeram remissão às bases ditadas neste Decreto Legislativo. ${ }^{19}$

ii.- Estabeleceu-se o caráter de continuidade do serviço público ao sancionar a descontinuidade ou suspensão por um $\mathrm{ano}^{20}$ do trabalho do caminho com a caducidade da concessão, salvo casos fortuitos ou de força maior. ${ }^{21}$ Estabeleceu-se também que “...as graças, exceções e privilégios concedidos pelo presente decreto à

\footnotetext{
${ }^{15}$ Artigo 5 das Bases do serviço.

${ }^{16}$ Artigo 6 das Bases do serviço.

${ }^{17}$ Artigo 11 das Bases do serviço. É claro que não se refere à propriedade privada, mas a uma classe de propriedade que qualifica como "particular", e que a iguala à propriedade pública. Daí o especial sistema de "proteção", estabelecido por lei.

${ }^{18}$ Cuja natureza jurídica é de lei em sentido formal, dada a natureza, por sua vez, de Estado Independente da Província de Buenos Aires e das potestades atribuídas à Honorável Sala de Representantes, primeiro órgão legislativo desse Estado. Coleção: "Leyes del Estado y Provincia de Buenos Aires, Periodo Legislativo IAño 1854-1855", p. 28-30.

19 Ver, por exemplo, Lei no 135, de 26 de junho de 1857, da Província de Buenos Aires, op. cit., "Leyes del Estado...", p. 232.

${ }^{20}$ Prazo outorgado para começar os trabalhos "...do caminho de ferro..." a partir da concessão do privilégio de realizá-lo, artigo 2, inciso $3^{\circ}$ do Decreto Legislativo de 9 de janeiro de 1854.
} 
sociedade da ferrovia, cessarão aos cinqüenta anos ou antes, se a ferrovia permanecer um ano sem funcionar". ${ }^{2}$

iii.-Previu-se, caso fosse necessário, ocupar terrenos privados para a construção da ferrovia, utilizar a potestade expropriatória “...para objetos do serviço público...", ${ }^{23}$ colocando a cargo da sociedade privada o pagamento das indenizações correspondentes. ${ }^{24}$

iv.-O Estado reservou-se o direito de propriedade e titularidade de até um terço das ações da sociedade anônima criada pela lei para a exploração do serviço. ${ }^{25}$ Isso constituiu um antecedente muito importante com respeito à participação do Estado nos resultados da exploração. Ou seja, estabeleceu-se uma concessão sob a modalidade onerosa.

v.- O Estado obrigou a concessionária a transportar de graça “...a correspondência pública e a força armada, ou artigos de guerra, toda vez que o Governo determinasse". ${ }^{26}$

O regime jurídico que surge da analisada lei de 9 de janeiro de 1854 , resulta, em minha opinião, uma antecipação visionária da posterior e, claro, mais elaborada, construção francesa da denominada Escola do Serviço Público. Isso demonstra a originalidade e a autonomia, tanto de nosso direito constitucional, como de nosso direito administrativo. ${ }^{27}$

Por outra parte, para o primeiro legislador de Buenos Aires, imediatamente posterior à sanção da Constituição de 1853, não existia diferença jurídica alguma entre as técnicas de concessão e licença para a prestação do serviço público por particulares. O conceito de licença intro${ }_{21}$ Artigo 2, inciso $13^{\circ}$.

22 Artigo 2, inciso $12^{\circ}$

${ }^{23}$ Artigo 2, inciso $6^{\circ}$.

${ }^{24}$ É muito interessante lembrar, como um claro sinal da origem das fontes de direito e portanto do ordenamento jurídico de referência levado em consideração pelos legisladores da época da sanção da Constituição Nacional de 1853, que no debate parlamentar da lei em questão, ao ser discutido em particular o mencionado inciso $6^{\circ}$, o Representante Tejedor manifestou que, do seu ponto de vista, não existia lei de expropriação aplicável ao território bonaerense, propondo então que fossem declarados de propriedade pública os terrenos por onde passasse a ferrovia. Diante disso "... os senhores Vélez Sarfield, Esteves Saguí e Azcuénaga opuseram-se à emenda dizendo que existia a lei de partida, que estabelecia o direito de expropriação; que havendo uma lei geral, era redundante fazer uma declaração particular, e que atualmente a mencionada lei estava sendo posta em prática no caminho da costa". "Diario de Sessiones de la Sala de Representantes, $1^{\circ}$ Sessión Ordinaria", de 2 de janeiro de 1854 . O critério levantado por eles triunfou na votação por 24 votos contra 3. É inegável a origem hispânica e de própria construção do Direito Pátrio da qual partiram nossos primeiros legisladores.

${ }^{25}$ Artigo 2, inciso $2^{\circ}$.

${ }^{26}$ Artigo 2 , inciso $8^{\circ}$.

${ }^{27}$ Defendi de maneira reiterada que deveria ser realizada uma reconstrução das bases de nosso direito administrativo em função de nossas próprias fontes, para determinar pelo menos algumas das causas dos problemas de funcionalidade que se advertem nesse sistema jurídico. Continua constituindo uma matéria pendente de nossa doutrina científica.

A \& C R. de Dir. Administrativo e Constitucional, Belo Horizonte, ano 5, n. 19, p. 11-34, jan./mar. 2005 
duzido obedece, a meu ver, a uma necessidade histórica e econômica que esses legisladores tiveram em vista. ${ }^{28}$

Só resta mencionar que às leis analisadas foram acrescentadas as de outros serviços públicos como as de Correios e Serviços de Mensagens (Estatuto de Fazenda e Crédito de 1853, que estabeleceu o serviço de Correios; Lei 52 de Serviços de Mensagens, de 1855). Após a unidade política da Confederação Argentina e do Estado e Província de Buenos Aires, foram sancionados na República Argentina os regimes de Faróis de 1872 e de Telégrafos pela Lei $7501 / 2$ de $1875 .^{29}$

Desde o início da Organização Nacional privilegiou-se a instauração desses serviços públicos. É significativa a Ata da Solene Abertura do Congresso Legislativo Federal e Primeira Sessão Ordinária do Congresso Legislativo da Confederação Argentina, de 25 de maio de 1855, onde o Presidente Urquiza disse:

“O campo de vossas tarefas é vastíssimo porque chegamos ao período administrativo. O Código fundamental espera, para melhorar seu desenvolvimento e aplicação, as leis que a tal efeito vossa sabedoria deve ditar...", e depois acrescenta como objetivo prioritário de desenvolvimento: "O estado da viabilidade em todo o território da Confederação, sem exceção alguma, é malíssimo, chegando a este doloroso extremo de não poder exportar valiosíssimos frutos, especialmente das Províncias do Norte, porque os gastos de transporte excedem o preço que têm nos mercados em que poderiam ser vendidos. A necessidade de melhorias é urgente e muito esperada em todos os povoados... (para isso) promovi com perseverança a empresa da construção de uma ferrovia de um ponto do Paraná à cidade de Córdoba e Cujo... obra tão grande quanto provei-

\footnotetext{
28 Para uma ampliação do que foi dito no texto, ver: SALOMONI, Jorge Luis, op. cit., "Teoria Geral...", p. 140 et seq.

29 "Durante vários anos negociou-se com a Europa a construção de uma ferrovia que uniria Córdoba a Rosário, porém as obras foram iniciadas somente na década seguinte. Os únicos serviços de transporte e de comunicações que foram inaugurados durante a Confederação foram os serviços de mensagens nacionais - serviços de diligências que uniam Rosário a diversos pontos do interior, mediante viagens regulares - e o serviço de navegação a vapor entre as cidades de Santa Fé e Paraná. Ambos os serviços, estabelecidos por concessionários privados... O correio Oficial também, reorganizado pelo Governo da Confederação, foi muito pouco usado pelos particulares. Apesar dos esforços do Governo, que baixou as tarifas, assegurou a inviolabilidade da correspondência e tratou de regularizar os serviços, os passageiros particulares continuaram sendo, por muito tempo, o principal veículo da correspondência privada. No entanto, o governo da Confederação conseguiu centralizar o serviço de correios. A reorganização foi realizada de forma similar à adotada para centralizar a arrecadação, tarefa que havia realizado anteriormente. Um inspetor, nomeado pelo Ministério da Fazenda, devia estabelecer as bases de um serviço postal uniforme nas Administrações de Rendas Nacionais, e ordenar aos administradores a centralização do serviço no âmbito de sua jurisdição.", e mais adiante continua dizendo: "... A existência e desenvolvimento das instituições estatais podem ser observadas como um verdadeiro processo de 'expropriação' social, no sentido de que suas criação e expansão implicam a conversão de interesses 'comuns' da sociedade civil em objeto de interesse geral e, portanto, em objeto de ação desse estado em formação. À medida que isso acontece a sociedade vai perdendo competências, âmbitos de atuação, nos quais até então havia resolvido — através de diferentes instâncias e mecanismos - as questões que requerem de decisões coletivas da comunidade...." (OSZLAK, Oscar. La Formación del Estado Argentino. Buenos Aires: Editorial de Belgrano, 1982, p. 63-64 e
} 
tosa para a prosperidade da Nação". ${ }^{30}$

A ferrovia e os outros serviços transformaram-se, assim, nos promotores da prosperidade da Nação. Dessa forma, intervenção do Estado serviço público - progresso da Nação, transformar-se-ão em estandartes do país.

Concordo plenamente com González Moras em que, a partir dos antecedentes pátrios antes mencionados, e depois de sancionada a Constituição Nacional de 1853, assim como em toda a normativa, jurisprudência e doutrina do direito público vigente até o começo do século XX, o conceito de "serviço público" será utilizado na República Argentina:

a) como conceito geral, para designar e dar conteúdo à função administrativa estatal colocada à disposição do público; ao interesse público ou geral; à titularidade pública ou estatal de determinada competência; para definir, definitivamente, a função pública nas normas gerais e especiais de organização administrativa;

b) para definir o regime de direito público a que estarão sujeitos determinados bens ou coisas por "estarem destinados" à atividade pública;

c) designará, também, o caráter conferido ao "uso público" de determinadas obras de infra-estrutura como, por exemplo, portos e caminhos;

d) Finalmente, e em sentido estrito, para designar e regular como tais, as atividades econômicas que forem consideradas públicas, que serão postas progressivamente sob a órbita e responsabilidade do Estado, apesar — inclusive — de sua gestão por sujeitos particulares, sendo esse o caso dos serviços de correios e mensagens, ferrovias, telégrafos, faróis, etc. Em outras palavras, para designar aquelas atividades que hoje denominaríamos "serviços públicos econômicos".

O fato de ter sido possível desenvolver de maneira tão extraordinária, nessa etapa histórica do país, um conceito como o de Serviço Público, que só seria "descoberto" pela chamada escola francesa do serviço público nas primeiras décadas do século XX, e com o alcance que acabamos de precisar, demonstra, claramente, não só a coerência entre uma idéia de

\footnotetext{
${ }^{30}$ Coleção "Congreso Federal del Paraná - Leys sancionadas en 1855", p. 6 e 8. Para corroborar a i mportância conferida por Urquiza aos outros serviços públicos - Correios, Serviços de Mensagens, etc., ver: op. cit., p. 17 et seq.
}

A \& C R. de Dir. Administrativo e Constitucional, Belo Horizonte, ano 5, n. 19, p. 11-34, jan./mar. 2005 
Estado e a de sua ação administrativa, como também, e fundamentalmente, a originalidade de nosso direito público, anterior a todo elemento que pudesse proceder, naquele momento, tanto do direito público norteamericano, como do francês ou do europeu continental.

Direito público nacional que, posteriormente, e a princípios do século XX, seria abrupta e incompreensivelmente colocado de lado pelos primeiros tratadistas do direito administrativo argentino, e pela Corte Suprema de Justiça da Nação. ${ }^{31}$

Confirmando o que foi exposto, é possível mencionar a primeira doutrina científica de direito administrativo em nosso país, publicada em 1866 e intitulada "Direito Administrativo Geral e Argentino" do Fiscal Geral da Nação, Ramón Ferreira, que continha uma menção explícita do serviço público como compreendendo a totalidade da atividade normal da Administração. De fato, referindo-se ao cumprimento da ordem constitucional do fomento e prosperidade da indústria e do país, estabelece a obrigação da Administração de dar impulso ao comércio, facilitar a comunicação entre os povoados, construir diversas obras, etc., através de diversos meios:

Tudo isso recai sob a palavra de obras públicas em geral; e todas as construções para o serviço público em todos os ramos da administração, necessárias para o culto, a instrução pública, justiça, beneficência, fazenda, milícia, marinha, comodidade, recreios e monumentos públicos e nacionais. Todos são necessários para a existência e felicidade da sociedade; por essa razão devem ser custeados com fundos do tesouro geral e devem servir para todos, igualmente ao rico e ao pobre, porque o que tem deve contribuir para o que não tem, para o bem de todos. ${ }^{32}$

\footnotetext{
31 GONZÁLEZ MORAS, Juan M., op. cit., conferência "El Concepto de Servicio Público". Considero muito importante destacar o Prefácio da primeira edição (1921) do Tratado de Direito Administrativo de um dos construtores da concepção de nossa disciplina imperante na Argentina. Refiro-me ao Sr. Rafael Bielsa. Em seu terceiro ponto, chama a atenção sobre algo que se torna evidente ao longo do texto: "A bibliografia, tanto a geral como a especial, distribuída em diversos capítulos é, como se verá, em sua maior parte, estrangeira, mesmo quando deveria ser, por tratar-se desta matéria, principalmente nacional. Não me esqueço, não, de trabalhos notáveis como o Tratado de Direito Administrativo Argentino, de Ramón Ferreira, obra escrita há mais de meio século; nem das interessantes dissertações do malogrado professor Lucio V. López, em seu Direito Administrativo Argentino, nem de outras que revelam encomiáveis esforços de seus autores. Entretanto, apesar de tudo, não podemos dizer de nosso direito administrativo o mesmo que do direito constitucional, matéria em que contamos com excelentes tratados, teses, e monografias". (BIELSA, Rafael. Derecho Administrativo. 6. ed. Buenos Aires: La Ley, 1964, p. 5). A bibliografia utilizada a que faz referência é, majoritariamente, francesa e italiana. Acredito que o problema não era o insuficiente desenvolvimento da doutrina jus administrativista argentina, mas a necessidade de substituir essa construção por outra - pois não eram compatíveis - que pudesse ser contraposta ao outro grande mito argentino, a idéia de ter una constituição norte-americana. Bielsa quis, então, contrapor a esse mito, o mito de que nosso direito administrativo era continental europeu, preferentemente francês. A única perda nessa discussão mítica foi a da construção original do direito administrativo argentino, cuja congruência com o direito constitucional argentino de Alberdi e dos "Padres Fundadores", era absoluta.
} 
Por sua vez, referindo-se aos bens públicos, e depois de diferenciálos dos que formam o patrimônio do Estado, diz que:

Pela mesma razão, nos primeiros, a administração versa somente sobre o uso; sua ação orienta-se a dar-lhes destino geral e seus regulamentos, a assegurar o usufruto comum, melhorar suas condições em tudo o que for possível; nos segundos se exerce exclusivamente a propriedade e uso; e ambas as coisas podem ser aplicadas às necessidades do serviço público. ${ }^{33}$

Nesta mesma ordem de idéias, como uma continuidade conceitual, e após a unificação da República Argentina, foi sancionada a Lei de Ferrovias $\mathrm{n}^{\mathrm{o}}$ 531, promulgada em 18 de setembro de 1872, que estabeleceu no Capítulo I "Da via e de sua conservação", artigo 3, e no que aqui interessa, que: "São deveres de toda empresa ou direção dessas ferrovias, uma vez abertas ao serviço público...”. ${ }^{34}$

A mencionada lei de 1872 de Ferrovias foi substituída pela Lei ${ }^{\circ}$ 2.873, de 1891. Embora as atividades de serviço público ferroviário tivessem começado no país no momento da Organização Nacional, foi somente com esta lei que se estabeleceu uma regulamentação de caráter geral abrangendo todos os aspectos da exploração.

No debate parlamentar sobre a regulamentação o Membro Informante, Senador Gil, afirmou que a ferrovia constituía um serviço público e portanto o Estado não podia desentender-se da prestação de seus serviços nem tampouco deixar sua regulamentação em mãos de particulares. ${ }^{35} \mathrm{O}$ serviço público, então, consolida-se como título de intervenção. Além disso, a legitimidade da intervenção estatal na administração da empresa concessionária é justificada pelo monopólio outorgado pelo Estado. Isso levava necessariamente, a estabelecer a uniformidade da tarifa e a obrigação de que fosse justa e razoável. ${ }^{36}$

Por outra parte o Sr. Zapata, e no que aqui interessa, disse:

Eu não posso esquecer que toda lei de ferrovias pode ser considerada lei de ordem pública. Expropria-se a propriedade particular para servir ao público; são estabelecidas serventias para servir ao público; decidem-se monopólios para servir ao público; as empresas recebem exoneração de direitos para os materiais utilizados para construir as obras. Todos esses privilégios, todas essas

\footnotetext{
32 FERREYRA, Ramón. Derecho Administrativo General y Argentino. Buenos Aires: Imprenta de Pablo E. Coni, 1866, p. 74-75

${ }^{3}$ FERREYRA, Ramón, op. cit., "Derecho Administrativo...", p. 110.

${ }^{34}$ Adla, 1852-1880, p. 947 et seq

35 "Diario de Sessiones del Senado", 1890, p. 232.

36 "Conforme o conceito básico da lei 2873, as tarifas, além de sua uniformidade, têm que ser 'justas' e 'razoáveis'. É muito importante estabelecer o alcance destas palavras. Um relatório produzido em 1918
} 
concessões, todas essas vantagens, são dadas por uma lei como esta porque ela vai beneficiar o serviço público. Por conseguinte tudo o que, em favor do interesse público, a lei fizer, estará perfeitamente bem feito. E não será demais, pelo contrário, se não fosse feito, seria de menos. ${ }^{37}$

E, mais adiante, para justificar a sanção da lei em debate, descreveu a situação que havia sido gerada pela falta de controle estatal das concessões:

Existe uma lei, Senhor Presidente, que se chama Lei Geral de Ferrovias e que é cópia da que regia no Chile em 1872 com o nome de Polícia de Ferrovias. Nós, os argentinos, ao copiar essa lei, incorremos em uma gravíssima omissão, porque nos esquecemos de criar a autoridade que devia aplicá-la. $O$ que aconteceu? Aconteceu que, por falta da autoridade que devia aplicar essa lei, na Republica Argentina não havia quem decidisse sobre a conveniência de construir uma ferrovia em tal ou tal ponto; não havia quem aconselhasse o Congresso sobre que bitola seria mais conveniente, se a larga ou a estreita; se a construção devia ser realizada diretamente pelo Governo ou com garantia da Nação, ou pelo impulso dos próprios particulares. Enfim, não se sabia o que a Nação havia gasto na construção direta das ferrovias; não se sabia o que havia pago pelas garantias oferecidas às empresas de ferrovias, e não se sabia tampouco o que deveria ser gasto nessas garantias. ${ }^{38}$

Tudo isso, ia contra as potestades de intervenção que se reconhecia ao Estado e que surgia do próprio ordenamento jurídico aplicado.

Por outra parte, é possível afirmar que essa potestade de intervenção

\footnotetext{
pelo engenheiro Pablo Nogués, da Direção Geral de Ferrovias, dizia: 'A justiça das tarifas, considerada com absoluta prescindência da maior ou menor utilidade que as tarifas possam proporcionar ao público, refere-se à relatividade dos gravames impostos e exige: a) Que para todas as distâncias às quais o transporte possa ser promovido, o frete seja maior do que o gasto efetivo que ele ocasiona (direto e de manutenção); b) Que, para um mesmo produto, os fretes cresçam com as distâncias, seguindo uma lei contínua de variação e, dessa forma, que o pedágio represente, sobre a parte do valor de transporte que fica livre, uma vez deduzidos os gastos efetivos, uma proporção crescente ou, pelo menos, constante com as distâncias; e c) Que para os diferentes produtos que deixem uma igual utilidade livre por quilômetro percorrido, seja igual ao valor quilométrico do transporte. A razoabilidade das tarifas, em rigor, está em que, admitindo que uma determinada utilidade pode ser conseguida por meio de diversos sistemas de tarifas, estabelecidas com os princípios mencionados, o justo e razoável será aquele que proporcionar a maior utilidade aos interesses gerais, no sentido de que seja máxima a soma de produtos transportáveis.. Por essa razão, está dentro das faculdades do Poder Executivo: 1. Fazer com que as utilidades obtidas pelas empresas, sejam conseguidas com o maior benefício para os interesses gerais, ou seja, com o maior rendimento ou utilização da linha. E, 2. Exigir que, se o sistema de tarifas se afasta do fundamental ou quilométrico, o que equivale a dizer que se recorre a tarifas diferenciais (tanto a respeito das distancias quanto aos valores de transporte dos diferentes pontos), estas se enquadrem nas normas e princípios fundamentais que presidem o estabelecimento de tais tarifas. Em resumo, o artigo 9 da 5315, deve ser interpretado como regulamentário do artigo 44 da lei geral de ferrovias, no sentido de que estabelece que a justiça e razoabilidade das tarifas, do ponto de vista da utilidade que proporciona às empresas, fica fixada no rendimento máximo de 6,8 por cento sobre o capital investido. De acordo com nossa legislação, pode-se dizer, então, que corresponde às empresas o direito de obter uma utilidade dentro das limitações marcadas, enquanto incumbe ao Poder Executivo estabelecer o melhor modo e a forma em que devem consegui-la". (ZABALíA, Clodomiro. Derecho Federal. 3. ed. Buenos Aires: Compañía Argentina de Editores, 1941, t. II, p. 719-721).

37 "Diario de Sessiones del Senado", 1890, p. 239.
} 
do Estado, com relação à concessão de privilégios, foi de tal magnitude que chegou a inverter o princípio de fixação das tarifas pelo próprio Estado, para conferir esse privilégio aos particulares. Se não fosse um privilégio, não seria necessário estabelecê-lo expressamente na lei, pois para as outras atividades econômicas regia a liberdade absoluta de preços. Não que a atividade regulamentada fosse privada, mas constitui uma mostra da magnitude do privilégio que o Estado podia outorgar para o cumprimento da Cláusula do Progresso e em razão do serviço público, que era, por sua vez, uma das técnicas de intervenção prevista na cláusula constitucional. ${ }^{39}$

Em função do que foi exposto, o concessionário fixou as tarifas desde as primeiras concessões até 1891 , ano em que, por meio da Lei $\mathrm{n}^{\circ}$ 2.835 , foi restabelecida a potestade do Poder Executivo de fixar as tarifas. ${ }^{40}$ O artigo 6 da mencionada lei, prescreveu que: "O Poder Executivo intervirá na formação das tarifas de todas as ferrovias levando em consideração os interesses gerais do país e as leis de contratos de concessão". ${ }^{41}$

Finalmente, foi sancionada a Lei 5.315, sobre a qual se disse:

Foi um passo de muita importância no terreno das relações entre as empresas ferroviárias e o governo, o que se deu em 1907 ao ditar-se a lei 5315, chamada 'Lei Mitre', por ter sido o engenheiro Emilio Mitre, em sua condição de deputado nacional, quem a projetou. Até esse momento cada empresa se regia por 38 "Diario de Sessiones del Senado", 1890, p. 256.

39 Preciso remarcar que a concepção defendida no texto foi duramente criticada pela Junta Consultiva de Advogados de Ferrovias, criada em 1925, e cujos membros eram, naquele momento: Presidente: Dr. Guillermo E. Leguizamón; Vice-presidente: Dr. Emilio F. Cárdenas; Vogais: Dr. Pedro F. Agote, Dr. Eduardo Bidau, Dr. Rodolfo Bullrich, Dr. Francisco Costa Paz, Dr. Gaspar E. Ferrer, Dr. Norberto M. Fresco, Dr. S.A. Klappenbach, Dr. Luis García Lagos, Dr. Alberto V. López, Dr. Manuel Moyano, Dr. Cayetano J. Mosciaro, Dr. Miguel M. Padilla (filho), Dr. Raimundo Real, Dr. Vicente Rivarola, Dr. Luis J. Roca, Dr. Osvaldo Rocha e Dr. Ramón Videla. ("Boletín de la Junta de Abogados de Ferrocarriles". Buenos Aires: Talleres Gráficos Argentinos de L. J. Rosso y Cía., 1925, t. I, p. 87). Esses advogados, que representavam as sociedades anônimas inglesas concessionárias das ferrovias, opuseram-se terminantemente à possibilidade de o Estado intervir nas tarifas. (Em op. cit., p. 3 et seq.). Esse setor apoiava, majoritariamente, por outro lado, a origem norteamericana de nossa norma constitucional. (Ver nota $n^{\circ} 31$ para a discussão com relação ao direito administrativo).

40 "A Corte Suprema disse sobre o particular: 'A absoluta liberdade de contratar e de fixar o preço das coisas ou serviços existe somente quando a propriedade ou a atividade pessoal encontram-se dedicadas a objetos puramente privados. Quando são de uso público, especialmente se explora alguma concessão, privilégio ou monopólio concedido pelo Estado, como ocorre precisamente no caso que se trata nesta litis, o proprietário ou concessionário acha-se submetido, pelo caráter da dedicação de sua atividade e pela própria natureza do favor que the foi outorgado, a um controle especial por parte da autoridade administrativa, controle que compreende também o ponto relativo ao preço ou tarifa compensatória do serviço que está encarregado de prestar. Isso justifica-se tanto pelo fato de a autorização ter sido conferida para exercer funções que, em princípio, correspondem ao Estado ou dependem de uma concessão do mesmo, quanto porque, significando o privilégio conferido um monopólio real ou virtual, a absoluta liberdade de fixar os preços ou também com relação aos controles, submeteria o público, que não pode prescindir de tais serviços, à opressão econômica dos concessionários (doutrina da sentença, tomo 136, página 161 e outros). Como conseqüência, toda concessão do Estado para a exploração de serviços públicos que envolver um monopólio, mesmo quando for somente virtual — como é o caso das ferrovias, leva implícita a condição de que seus preços ou tarifas sejam submetidos ao controle da autoridade administrativa correspondente'. (FALLOS, t. 146, p. 232)". (ZABALÍA, Clodomiro, op. cit., "Derecho...", p. 727-728). 
sua respectiva lei de concessão, surgindo por isso muita disparidade no desenvolvimento de atividades susceptíveis de serem realizadas de acordo com um critério legal e regulamentar uniforme. O termo das concessões não era igual e variava também, consideravelmente, o capítulo das obrigações impositivas. ${ }^{42}$

Tudo o que foi exposto, independentemente das doutrinas jurídicas continentais européias e de sua oposta, a norte-americana, que tanto influenciaram distintos setores da doutrina nacional, permite afirmar que, tanto Alberdi, principal fonte de nossa Constituição, ${ }^{43}$ quanto os primeiros legisladores, partiram de uma teoria do Estado em que este devia intervir ativamente, tanto atuando per se, ou aspecto positivo, quanto deixando que os indivíduos atuassem, ou aspecto negativo. Isso leva à afirmação de que o Estado vertebrado não era neutro. O objetivo eram o desenvolvimento e o progresso. Os sujeitos, o Estado e os particulares, em parte iguais. Os meios, o fomento da imigração e, com ela, o fomento da colonização de terras públicas; a liberdade de comércio, a instalação e concessão de serviços públicos essenciais para o fim perseguido — caminhos de ferro —, podem ser consideradas como algumas das tarefas públicas e privadas distribuídas pela Constituição entre o Estado e os particulares.

\footnotetext{
${ }^{41}$ Adla, 1889-1919, p. 224.

${ }^{42}$ ZABALÍA, Clodomiro, op. cit., "Derecho...", p. 733-734. No mesmo sentido, ver: SAMMARTINO, Ermete A. Elementos de Derecho Administrativo. Buenos Aires: Editado por Pedro M. Aquino y Cía. Libreros Editores, 1929, p. 99.

${ }^{43}$ Como afirmei em outra oportunidade: "...a cláusula do artigo 67 inciso 16 (hoje 75 inciso 18), que atribui determinadas potestades legislativas ao Congresso da Nação, na redação original feita pelos constituintes e que foi mantida depois da Reforma de 1994, não encontra similar na Constituição dos Estados Unidos da América. Como se disse no Capítulo precedente, Alberdi em "Las Bases y Puntos de Partida para la Organización Política de la Republica Argentina", afirmou que as fontes da norma mencionada eram: "O tratado litoral, firmado em Santa Fé em 4 de janeiro de 1831 por três províncias importantíssimas da República, ao qual depois aderiram todas, e que acaba de ser ratificado pelo acordo de San Nicolás, de 31 de maio de $1852 \ldots$. . . Ou seja, reconhece sua origem no direito pátrio, na própria concepção alberdiana do Estado, e não em fonte estrangeira alguma. Por outro lado, a redação atual da norma analisada reconhece como antecedente o artigo 67 inciso $3^{\circ}$ do "Projeto de Constituição concebido conforme as Bases desenvolvidas neste livro", que parte da concepção do Estado explicitada no Capítulo precedente. Isto é, o Estado provedor, estimulador, garantia, devedor, da prosperidade, defesa, segurança, progresso e bem-estar da Nação, através das técnicas de: a) leis protetoras desses fins, b) concessões temporárias de privilégios e c) recompensas de estímulo. Foram cobertas desde a instrução pública, a indústria, a introdução de capitais estrangeiros, até a construção de ferrovias. Cabe esclarecer, em minha opinião e no que aqui importa, que a norma constitucional argentina estabeleceu dois planos, bem diferenciados entre si, que tutelaram bens jurídicos diferentes: por um lado, o estímulo e fomento dos bens privados, isto é, a garantia da liberdade econômica e o dever do Estado de apoiá-la; e por outro lado, a obrigação de provisão dos bens públicos, através do próprio Estado ou de seus concessionários. Isso incluiu tudo o relativo aos serviços públicos. É evidente que o conceito "ferrovias" incluía o de "serviços públicos", e também identificava um modelo de Estado e, por essa razão, um importante grau de intervenção na economia. Esse grau de intervenção, que não encontrava limites jurídicos, justificava-se, tanto do ponto de vista da obrigação do Estado de propender ao "progresso material do país", como do afiançamento "da paz e da tranqüilidade da República". Coincide em sua totalidade, por outra parte e como vem sendo afirmado, com a concepção alberdiana do Estado esboçada no "Fragmento...". (SALOMONI, Jorge Luis, op. cit., "Teoría Geral...", p. 129-131).
} 


\section{Conceito atual de Serviço Público}

Posso afirmar que a evolução jurisprudencial que acompanhou o processo constitucional e legislativo nos primeiros 25 anos do século XX não variou muito com relação aos conceitos e padrões do século XIX analisados mais acima. Isso, independentemente das diferentes etapas pelas quais atravessou o serviço público em sua prestação preferente pelos particulares - a primeira metade do século - e pelo Estado — os seguintes quarenta anos - . A atividade serviçal era de titularidade estatal e podia ser prestada por particulares delegados ou reservar-se o estado para essa prestação com exclusão expressa daqueles particulares. O regime jurídico aplicável às relações Estado-concessionário era de direito público e os caráteres de regularidade, obrigatoriedade, uniformidade e igualdade encontravam recepção normativa nas bases do serviço.

Com o processo de Reforma do Estado de 1989, produz-se, no entanto, um fenômeno singular. Promove-se uma delegação de concorrência na prestação dos serviços públicos que vem provocar uma discussão, ainda não acabada, sobre a configuração do conceito do mesmo, e portanto do regime jurídico aplicável ao serviço.

Alguns sustentaram que tal processo de Reforma provocou uma mudança radical nos conceitos tradicionais, ao adotar a legislação emergente, o sistema jurídico norte-americano, devendo-se portanto, e para a compreensão do novo fenômeno, estudar e analisar as instituições estabelecidas nesse direito e suas pautas hermenêuticas de aplicação. Mais ainda se levarmos em consideração a procedência norte-americana de nossa Constituição. ${ }^{44}$

Outros, reivindicando a tese de que nosso direito administrativo seguia pertencendo à órbita do direito continental europeu, observaram uma continuidade do conceito, modulada pelos princípios de desregulamentação e liberalização do serviço que traduziam um modelo melhorado e moderno do sistema serviçal tradicional, mesmo considerando a originalidade do nosso sistema constitucional. ${ }^{45}$

Gostaria de ressaltar que não subscrevo, em sua totalidade, nenhuma das duas teses que acabo de mencionar, embora alguns contornos se conectem com minha tese. Meu ponto de partida é que o serviço público

\footnotetext{
${ }^{44}$ Esta concepção foi sustentada, fundamentalmente, pelo prestigioso professor Héctor Mairal em "La Ideología del Servicio Público". Revista de Derecho Administrativo, Buenos Aires, n. 14, set./dez. 1993, p. 359 et seq., entre outros artigos de sua autoria.
}

A \& C R. de Dir. Administrativo e Constitucional, Belo Horizonte, ano 5, n. 19, p. 11-34, jan./mar. 2005 
foi uma concepção original e autônoma de nosso país, que atravessou nossa história, como ficou demonstrado mais acima, ${ }^{46}$ e que hoje está modulada fundamentalmente pelo sistema de direitos humanos, como tentarei explicar mais abaixo. Por outro lado, sustento que o processo de Reforma do Estado, por meio da legislação ditada a esses efeitos, não produziu modificação sustentativa alguma à concepção original.

Aos efeitos da análise que me proponho, sustentarei, seguindo uma doutrina não discutida por nenhum dos setores acima mencionados, que no serviço público se encontra indefectivelmente presente o interesse público. Este último constitui o gênero e o serviço público uma das espécies possíveis.

Para a confirmação de tal pressuposto, deve-se estabelecer como se determina a presença do interesse público ou interesse geral em uma instituição jurídica.

Para tal cometido é necessário descobrir o propósito público da norma pela qual se instaura um determinado regime jurídico. O problema consiste, então, em descobrir o propósito público do serviço público. ${ }^{47}$

É indubitável que o mesmo é a satisfação das necessidades materiais coletivas mediante atividades econômicas que devam ser asseguradas pelo Estado para alcançar, conjuntamente com essa satisfação, o bem-estar geral do Preâmbulo da Constituição, que se configura, para o tema em estudo, nas denominadas Cláusula da Prosperidade ou Progresso do artigo 75 inciso $18^{48}$ na Cláusula do Desenvolvimento Humano do artigo 75 inciso $19^{49}$ e nas Medidas de Ação Positiva de garantia da igualdade de oportunidades e de trato e do pleno gozo e exercício dos direitos reconhecidos na Constituição do artigo 75 inciso $23 .{ }^{50} \mathrm{E}$ tudo isso, através, por sua vez, de uma regulamen-

\footnotetext{
45 Podemos colocar o eminente professor Juan Carlos Cassagne como encabeçador desta concepção se observarmos o ser artigo "El Servicio Público e las Técnicas Concesionales". Revista de Derecho Administrativo, Buenos Aires, n. 18, jan./abr. 1995, p. 21 et seq., entre outros artigos de sua autoria. Pode-se destacar na doutrina argentina a última reelaboração autorizada desta teoria efetuada pelo eminente professor Julio Rodolfo Comadira. Ele sustentou que: "O serviço público como título exorbitante próprio do direito Administrativo, invocado por um Estado que não deve renunciar sua função gestora do bem comum, é o meio de assegurar a obrigatoriedade devida ao usuário, mediante o controle e a regulamentação policial ou, quando for o caso, a prestação direta — com titularidade ou sem ela — indireta. O serviço público é, pois, exorbitância, prerrogativa e garantia". (COMADIRA, Julio Rodolfo. El Servicio Público como Título Exorbitante. El Derecho-administativo, n. 10912, 31 dez. 2003).

${ }^{46}$ Reitero que para uma ampliação sobre a originalidade da norma constitucional aargentina e do conceito de serviço público, ver: SALOMONI, Jorge Luis, op. cit, "Teoría General"..., Caps. I e II.

${ }^{47}$ Assim sustentou a Corte Suprema de Justiça da Nação: "Que corresponde examinar em primeiro termo qual é a doutrina, o conceito de propósito público, referido ao imposto. Desde já não é possível estabelecer uma regra uniforme que permita determinar quais propósitos são públicos, por oposição a privados. Dificilmente uma lei de benefício público não contenha algum elemento de proveito pessoal e dificilmente uma lei de propósito privado não encerre repercussões de benefício público. O critério para
} 
tação especial, e da prestação per se do Estado ou através de seus delegados. Se o serviço público persegue um propósito público, então ele se identifica com o interesse público. ${ }^{51}$ Como foi dito, o serviço público seria uma das formas específicas que adota o interesse público como instituição genérica. Isso implica a existência de um regime de direito público que regulamenta a instituição, e que exclui, em sua formulação original, a possibilidade de um regime de direito privado.

A segunda conseqüência que surge de tal regime é a impossibilidade de propriedade ou titularidade privada dos concessionários e/ou licenciatários sobre o direito de prestar o serviço. Uma vez que se obtém esse direito, mediante o regime de direito público mencionado, o mesmo estará sempre condicionado ao cumprimento desse regime de direito originário, mesmo quando este se remeter a determinadas normas do direito privado particular e concreto. Não se deve entender que a palavra público, quando empregada em relação ao poder de criar impostos (diz James Gray transcrevendo a sentença do Juiz Cooley), deve ser interpretada ou aplicada em sue sentido estrito ou antiliberal ou com um alcance que impeça a legislatura de tomar amplas vistas sobre o interesse, necessidade ou polícia do Estado dando-lhes efeito por meio das rendas públicas. O limite da autoridade do Estado nesta direção não pode ser definido e se acha constituído por seu amplo critério de homem do Estado que olha, além dos gastos que são absolutamente indispensáveis, para a continuada existência do Governo, e compreende outros tendentes a contribuir para o bemestar geral da sociedade e antecipa ao presente a futura felicidade do povo. Construir edifícios públicos, pagar aos funcionários do Estado e a dívida pública não são os únicos fins aos quais as rendas públicas podem ser aplicadas. Ao contrário, razões de natural equidade, gratuidade e beneficência não estão fora de lugar quando o bem-estar do povo se acha em questão e possam ser considerados na imposição das cargas públicas" ("Sociedad Anónima de Viñedos e Boderas Arizú c/ Província de Mendoza s'inconstitucionalidade das leis número 854 e 928", de data de 16 de junho de 19930, Sentenças: 157:359).

${ }^{48}$ Artigo 75: Corresponde ao Congresso:... 18. Proporcionar o condizente para a prosperidade do país, para o a a a c o e b e m-estar de todas a s províncias, assim como para o progresso da ilustração, ditando planos de

instrução geral e universitária, e promovendo a indústria, a imigração, a construção de ferrovias e canais navegáveis, a colonização de terras de propriedade nacional, a introdução e estabelecimento de novas indústrias, a importação de capitais estrangeiros e a exploração dos rios interiores, por leis protetoras destes fins e por concessões temporais de privilégios e recompensas de estímulo".

49 "Artigo 75: Corresponde ao Congresso:... 19. Propiciar o condizente ao desenvolvimento humano, ao progresso econômico com justiça social, à produtividade da economia nacional, à geração de emprego, à formação profissional dos trabalhadores, à defesa do valor da moeda, à pesquisa e desenvolvimento científico e tecnológico, sua difusão e aproveitamento. Proporcionar o crescimento harmônico da Nação e o povoamento de seu território; promover políticas diferenciadas que tendam a equilibrar o desigual desenvolvimento relativo de províncias e regiões. Para estas iniciativas, o Senado será Câmara de origem. Sancionar leis de organização e de base da educação que consolidem a unidade nacional repeitando as particularidades provinciais e locais; que assegurem a responsabilidade indelegável do estado, a participação da família e da sociedade, a promoção dos valores democráticos e a igualdade de oportunidades e possibilidades sem discriminação alguma; e que garantam os princípios de gratuidade e equiedade da educação pública estatal e a autonomiia e autarquia das universidades nacionais. Ditar leis que protejam a identidade e pluralidade cultural, a livre criação e circulação das obras do autor; o patrimônio e os espaços culturais e audiovisuais".

50 Artigo 75: Corresponde ao Congresso:... 23. Legislar e promover medidas de ação positiva que garantam a igualdade real de oportunidades e de tratamento, e o pleno gozo e exercício dos direitos reconhecidos por esta Constituição e pelos tratados internacionais vigentes sobre direitos humanos, em particular no que diz respeito às crianças, às mulheres, aos anciãos e às pessoas com deficiências. Ditar um regime de segurança social especial e integral em proteção da criança em situação de desamparo, desde a gravidez até a finalização do período de ensino fundamental, e da mãe durante a gravidez e o tempo de lactância".

${ }^{51}$ Também a Corte Suprema nacional estabeleceu o seguinte princípio: "Este serviço (exploração de depósitos

A \& C R. de Dir. Administrativo e Constitucional, Belo Horizonte, ano 5, n. 19, p. 11-34, jan./mar. 2005 
como complementárias daquele. E esse direito nunca é anterior ao outorgamento do título ou direito.

Os caráteres de obrigatoriedade, de regularidade (que compreende a sujeição do prestador às regras do serviço, e aos níveis de quantidade e qualidade exigidos) e de uniformidade do serviço, determinam a satisfação da necessidade pública e é conseqüência necessária do regime de direito público que a estabelece.

A liberalização e/ou monopólio do serviço não determinam, em nenhum caso, o caráter da atividade como serviço público ou privado.

Mas o asseguramento da atividade responde, não ao âmbito disponível da potestade do legislador ou administrador nacionais ou provinciais, mas sim à exigência do direito fundamental à sustentação dos serviços públicos estabelecido na Declaração Americana dos Direitos e Deveres do Homem no artigo 42 da Constituição Nacional. ${ }^{52}$

O artigo XXXVI da mencionada Declaração Americana, que ostenta hierarquia constitucional como estabelece o artigo 75 , inciso $22,2^{\circ}$ parágrafo da Constituição Nacional, ${ }^{53}$ estabelece que: "Dever de pagar impostos: Toda pessoa tem o dever de pagar impostos estabelecidos pela lei para a sustentação dos serviços públicos.”

Em primeiro lugar, a norma impõe correlativamente o dever de pagar impostos, o direito a receber os serviços públicos necessários para seu desenvolvimento pessoal e social. Também especifica que entre os possíveis propósitos públicos que podem garantir por meio do gasto das rendas do erário público, o que se deve garantir às pessoas é, precisamente, a sustentação dos serviços públicos, como prioridade e contrapartida, pela obrigação de pagar impostos desses indivíduos. Em segundo lugar, pelo pagamento de impostos, adquire-se o direito ao serviço. Isto é, o pagamento

\footnotetext{
fiscais) era de utilização obrigatória e se remetia essencialmente ao movimento de mercadorias dentro do porto. Estava dado não em benefício de quem o prestava, mas sim para satisfazer um interesse geral. Havia na exploração um interesse público diretamente contemplado, motivo pelo qual o serviço devia ser executado de forma obrigatória, regular e uniforme. Do dito se infere o caráter de serviço público da prestação encomendada" (Considerando 6). ("S.C.A. Meridiano v. Administración General de Puertos s/ demanda danos e prejuízos", de 24 de abril de 1979, Sentenças 301:292).

52 Esta postura que sustento há já alguns anos está sendo desenvolvida na Espanha pro Lorenzo MatínRetortillo Baquel, que sustentou que o artigo 36 da Carta dos Direitos Fundamentais da União Européia, "...reconhece e respeita o acesso (ao serviço público), no sentido de tratar-se de uma das garantias próprias de um direito fundamental, pois tal é em definitiva o alcance de uma das peças de uma Carta de Direitos Fundamentais". E acrescenta que é destacável "... que se dê cabida expressa no preceito à tecnologia que o inspira, essa afirmação que conclui destacando que o que regulamenta é 'com o fim de promover a coesão social e territorial da União'". O direito de acesso aos serviços de interesse econômico geral (O artigo 36 da Carta dos Direitos Fundamentais da União Européia), em op. cit., VVAA. Estudios de Derecho Público Económico..., p. 519-520.

${ }^{53} \mathrm{O}$ mencionado artigo estabelece que: "...A Declaração Americana dos Direitos e Deveres do Homem; a
} 
de qualquer imposto, como o é o valor agregado ou consumo, pago por todas as pessoas na República Argentina, outorga-lhe o direito a exigir a prestação dos serviços públicos indispensáveis para seu desenvolvimento pessoal e humano. Elimina-se a categoria de usuário potencial e usuário efetivo.

Por sua vez o artigo 42 da Constituição Argentina estabelece que:

Os consumidores e usuários de bens e serviços têm direito, em relação de consumo, à proteção de sua saúde, segurança e interesses econômicos; a uma informação adequada e veraz; à liberdade de escolha, e a condições de tratamento equitativo e digno.

As autoridades proporcionarão a proteção desses direitos, a educação para o consumo, a defesa da competitividade contra toda forma de distorção dos mercados, o controle dos monopólios naturais e legais, o da qualidade e eficiência dos serviços públicos, e a constituição de associações de consumidores e usuários.

A legislação estabelecerá procedimentos eficazes para a prevenção e solução de conflitos, e os marcos regulamentares dos serviços públicos de competência nacional, prevendo a necessária participação das associações de consumidores e usuários das províncias interessadas, nos organismos de controle.

Em primeiro lugar, e dentro do conceito genérico estabelecido na norma constitucional proveniente da Declaração Americana dos Direitos e Deveres do Homem, já citada anteriormente, especifica-se e reafirma-se a existência constitucional do serviço público na República Argentina, não como ideologia ou teoria, mas sim como direito positivo vigente e eficaz, em vinculação com os direitos do usuário do mesmo. ${ }^{54}$

Em segundo lugar, o continente e o conteúdo desse serviço público não são disponíveis para o legislador e o administrador. $\mathrm{E}$ isso é assim porque, dito instituto jurídico se encontra sistematicamente na parte dogmática da Constituição, isto é, nas Declarações, Direitos e Garantias e como tributário destes. O sistema obriga o legislador e o administrador a:

i - Estabelecer e regular o serviço público:

a - Resguardando a saúde, a segurança e os interesses econômicos dos usuários. Estes últimos primam sobre as potestades estatais de modificação tarifária assim como sobre os direitos de proDeclaração Universal dos Dirêitos Humanos; a Convenção Americana sobre Direitos Humanos; o Pacto Internacional de Direitos Civis e Políticos seu Protocolo Facultativo; a Convenção sobre a Prevenção e a Sanção do Delito de Genocídio; a Convenção Internacional sobre a Eliminação de todas a Formas de Discriminação Racial; a Convenção Contra o Tortura e Outros Tratamentos e Penas Cruéis, Desumanos ou Degradantes; a Convenção Sobre os Direitos da Criança; nas condições de sua vigência, têm hierarquia constitucional, não derrogam artigo algum da primeira parte desta Constituição e devem ser entendidos como complementares dos direitos e garantias por ela reconhecidos. Só poderão ser denunciados, quando necessário, pelo Poder Executivo Nacional, prévia aprovação de dois terços da totalidade dos membros de

A \& C R. de Dir. Administrativo e Constitucional, Belo Horizonte, ano 5, n. 19, p. 11-34, jan./mar. 2005 
priedade dos concessionários, licenciatários e/ou permissionários de serviços públicos de exigir tal modificação.

b - Garantindo uma informação adequada e veraz, que implica como contrapartida uma garantia de participação plena deste coletivo, mediante as associações de usuários de serviços públicos ou individualmente, em cada uma das etapas pré-contratual, contratual e pós-contratual, pelas quais se desenvolve o processo de colocação em funcionamento e prestação efetiva do serviço. ${ }^{55}$ c - Garantindo a liberdade de escolha e as condições de tratamento digno e equitativo.

d -Garantindo a educação para o consumo.

ii - Proteger e garantir o direito da concorrência contra toda forma de distorção dos mercados. No extremo da aplicação desta obrigação estatal encontra-se a plena liberalização do serviço de que se trate. E com isso a garantia do serviço universal, isto é, a prestação de mínimos de serviço para toda a população.

iii - O Controle dos monopólios naturais e legais.

iv -Garantir a qualidade e eficiência dos serviços públicos. Isso implica, por um lado e fundamentalmente, garantir a regularidade do serviço no que diz respeito à quantidade e qualidade do mesmo e, concomitantemente, ao apego às normas que o regulamentam. E por outro lado, garantir a obrigatoriedade e uniformidade do serviço.

v -Estabelecer procedimentos eficazes para a resolução de conflitos entre os sujeitos intervenientes na relação jurídica emergente do serviço.

vi -Ditar, mediante leis em sentido formal, os marcos regulamentares dos serviços públicos, de acordo com as diretivas antes

\footnotetext{
${ }^{54}$ Por outro lado, as normas constitucionais que estabelecem os direitos do contribuinte-usuário são plenamente operativas. Por norma operativa, auto-suficiente ou auto-aplicativa deve-se entender a que por natureza e formulação oferece aplicabilidade e funcionamento imediato e direto, sem necessidade de sua regulamentação por outra norma. (Conf. SALOMONI, Jorge Luis; BEZZI, Ana María; FRASCHERI, Ernestina. La Convención Americana de los Derechos Humanos e la Legitimación Procesal en el Contencioso Administrativo, p. 10, inédito). Por outro lado, e totalmente de acordo com o expressado precedentemente, a Corte Suprema da Justiça da Nação sustentou que: "Uma norma é operativa quando está dirigia a uma situação da realidade na qual pode operar imediatamente, sem necessidade de instituições que o congresso deva estabelecer" (In re: "Miguel Angel Ekmekdjian v. Gerardo Sofocich y outros" Sentenças; 315:1492, Considerando 20, primeiro parágrafo, fine).

55 Para uma análise exaustiva da participação das associações de usuários no controle da Administração Pública, ver: SALOMONI, Jorge Luis. El Control de la Administración Pública por las Organizaciones No Gubernamentales. In: WVAA. Control de la Administración Pública. Administrativo, Legislativo Y Judicial. Jornadas organizadas pela Universidade Austral. Buenos Aires: Edições RAP, 2003, p. 447 et seq.
} 
mencionadas.

vii-Estabelecer os órgãos de controle dos serviços públicos, garantindo a participação das associações de usuários e das províncias interessadas em ditos entes.

Esta norma produziu, em minha opinião, uma profunda modificação de legitimidade no sistema serviçal e concessional administrativo, ao introduzir o usuário como sujeito determinante. ${ }^{56}$

A norma constitucional em análise, como se viu, designa um sujeito credor: o usuário, e dois sujeitos devedores solidariamente responsáveis: o prestador do serviço e o Estado (artigo $42,2^{\circ}$ parágrafo C.N.)..$^{57}$

Esta qualificação constitucional dos direitos do usuário põe em dúvida um dos postulados sobre os quais se formula um sistema de direito administrativo como o nosso, como é o de considerar a Administração Pública vicário dos interesses gerais, já que sua co-titularização e exercício neste coletivo e para este caso concreto podem desarticular tal postulado. ${ }^{58}$

Estas questões me levam também a afirmar que o usuário é titular de um direito subjetivo pleno que lhe permite aceder irrestritamente à jurisdição judicial para a defesa desses direitos, isto é, a própria Constituição estabelece a garantia de defesa de seus direitos. ${ }^{59}$ Isso mediante as vias processuais comuns ou de exceção, ou mediante a via processual autônoma que denominei em outra oportunidade de Amparo ou "Contencioso dos Direitos Humanos" estabelecida nos artigos 8.1 e 25.1 da Convenção Americana dos Direitos Humanos. ${ }^{60}$

Todo o exposto estabeleceu um giro copernicano na concepção sobre os direitos do usuário, e fundamentalmente sobre o serviço público.

Não obstante isso, há muito que a Corte suprema de Justiça da Nação, mesmo sem a reforma constitucional de 1994, estabeleceu o interesse do Consumidor ou Usuário de um serviço público como o interesse público

\footnotetext{
${ }^{56}$ Desde a mais qualificada doutrina civilista argentina, ver os estudos relacionados aos direitos do consumidor dos professores Atilio Anibal Alterini, "Los Contratos de Consumo e las Cláusulas Abusivas", e Roberto M. López Cabana, "Los Dañnos al Consumidor y la Ley 24.240", ambos em Temas de Responsabilidad Civil (Faculdade de Direito e Ciências Sociais da Universidade de Buenos Aires - Edições Ciudad Argentina, 1995), e, Mosset Iturraspe, Jorge, Lorenzetti, Ricardo Luis, Defensa del Consumidor. Ley 24.240 (Rinzal-Culzoni, Editores, 1994).

${ }^{57}$ Isso é assim porque: "...o Estado está supraordinado ao cidadão unicamente na medida em que tal superioridade Ihe venha atribuída especialmente pela Constituição e pelas leis. O Estado (a Administração) é certamente uma pessoa jurídica, mas só por razão da medida de identificar o sujeito ao qual devem ser imputadas as correspondentes competências, ações e responsabilidades, resultando em todo caso suas faculdades - assim como os limites das mesmas — da constituição e das leis. Portanto, a posição deste específico sujeito (o Estado) e, por reflexo, a dos sujeitos de Direito ordinários ou normais (cidadãos) unicamente podem se derivar e construir a partir das normas e relações jurídicas que medeiam entre ambos:. (PAREJO ALFONSO, Luciano. Crisis e Renovación en el Derecho Público. Madri: Centro de Estudios Constitucionales, 1991, p. 109)

${ }^{58}$ Faz-se necessário revisar os postulados sobre os quais se construiu o direito administrativo décimonônico, sobretudo no que tange à relação jurídica emergente de tal ordenamento. Isso implicará, necessariamente, a reconstrução do sistema de direitos dos particulares e da sociedade, e do das potestades estatais.
} 
a proteger nessa relação de consumo. Sustentou que:

O artigo 46 da lei No 2873 é claro e preciso em sua letra e não pode ter mais que uma interpretação. Refere-se a 'frutos e provisões destinados ao consumo diário das populações que o transporte ferroviário comunique'. O que caracteriza esta carga para dar-lhe um tratamento especial é que seja destinada ao consumo diário da população. Uma mercadoria de tal caráter deve ser transportada com preferência, como também deve ter preferência a bagagem dos passageiros, as malas e a correspondência, etc., etc., segundo disposto pelo mesmo art. 46. E a regulamentação geral estabeleceu que este tipo de carga será transportado nos termos fixados pela Dirección General de Ferrocarriles (art. 220 do Regulamento aprovado pelo Decreto de 10 de setembro de 1894). Isso significa que em atenção ao interesse comprometido do público consumidor, não se podem convir para o transporte das mesmas tarifas especiais, prolongando os termos em troca de diminuições de fretes, como se pode fazer com as demais cargas (art. 49 da lei). Fora estes casos as mercadorias a transportar, qualquer que seja sua natureza, podem se submeter a tarifas especiais em que se prolonguem os tempos e em troca se reduzam os fretes, segundo convenham as partes; porque tratando-se de mercadorias gerais não está comprometido o interesse público e incumbe unicamente às partes negociar da forma que creiam mais favorável a seus interesses. O contrato cai somente então no domínio exclusivo da lei comercial cujas disposições, bem ou mal aplicadas, não interessam ao regime federal. ${ }^{61}$

Fica claro que para o tribunal, o interesse público está encabeçado pelos usuários - consumo diário de uma população - que devem ser abastecidos pelo serviço ferroviário, sem possibilidade de negociar as tarifas.

\section{Conclusão}

Serviço público, então e em minha opinião, é toda atividade econômica, regular, contínua e uniforme, que tem o propósito público de satisfazer eficazmente às necessidades materiais coletivas a cujo asseguramento está obrigado o Estado, tanto mediante a prestação per se ou por particulares delegados, para alcançar o bem-estar geral, e cujo sujeito credor é o contribuinte do erário público, titular do direito fundamental

\footnotetext{
59 "As garantias não são outra coisa que as técnicas previstas pelo ordenamento para reduzir a distância estrutural entre normatividade e efetividade, e, portanto, para possibilitar a máxima eficácia dos direitos fundamentais em coerência com sua estipulação constitucional. Por isso, refletem a diversa estrutura dos direitos fundamentais para cuja tutela ou satisfação foram previstas: as garantias liberais, ao estarem dirigidas a assegurar a tutela dos direitos de liberdade, consistem essencialmente em técnicas de invalidação ou de anulação dos atos proibidos que as violam; as gatantias sociais, orientadas como estão a assegurar a tutela dos direitos sociais, consistem, ao contrário, em técnicas de coerção e/ou de sanção contra a omissão das medidas obrigatórias que as satisfazem. Em todos os casos, o garantismo de um sistema jurídico é uma questão de grau, que depende da precisão dos vínculos positivos ou negativos impostos aos poderes públicos pelas normas constitucionais e pelo sistema de garantias que asseguram uma taxa mais ou menos elevada de eficácia a tais vínculos". (FERROJOLI, Luigi. Derechos e Garantías, La Ley del más Débil. Madri: Trotta, 1999, p. 25). O grifo é de minha autoria.

60 SALOMONI, Jorge Luis. Reglamentos de Necesidad e Urgencia: Análisis de la Justificabilidad de sua Incorporación al Plexo Constitucional. Sistema de Poder, Producción e Aplicación de la Norma. In: CASSAGNE, Juan Carlos (Diretor). VVAA. Estudios sobre la Reforma Constitucional. Buenos Aires: Depalma, 1995, nota 30, p. 234.
} 
ao acesso ao serviço e como usuário à prestação efetiva do mesmo, com preponderância de seus interesses econômicos com relação ao sistema de potestades estatais e aos direitos do prestador privado do serviço, em um regime especial de direito público.

Portanto, o conceito de serviço público, com a reforma da Constituição de 1994, não é autônomo ou inteiramente disponível para o legislador latu sensu mas está subordinado ao sistema de direitos do contribuinte-usuário prescritos pelo artigo XXXVI da Declaração Americana dos Direitos e Deveres do Homem e pelo artigo 42 da CN.

O âmbito de aplicação das normas mencionadas é federal, isto é, deve integrar todas as constituições provinciais no caso da ausência de regulamentação, e se estiver fora de caso, prevalecendo por sobre o que dispuser a norma provincial em contrário.

A pretensão deste trabalho, finalmente, não foi outra que a de fortalecer a tentativa de estabelecer um novo ponto de partida em nossa disciplina. Não de chegada. Este deveria permitir uma nova discussão sobre o, até agora perdurável, serviço público, distante de toda a ideologia e que tenda a uma estrita vinculação com o ordenamento positivo. Que assim seja.

Informação bibliográfica deste texto, conforme a NBR 6023:2002 da Associação Brasileira de Normas Técnicas (ABNT):

SALOMONI, Jorge Luis. O conceito atual de serviço público na República Argentina. A $\mathcal{E}^{\circ} C$ Revista de Direito Administrativo e Constitucional, Belo Horizonte, ano 5, n. 19, p. 11-34, jan./mar. 2005.

\footnotetext{
${ }^{61}$ Alberto S. Carvalho contra a Empresa del Ferrocarril Central Buenos Aires, sobre devolução de fretes", de 14 de novembro de 1938, sentenças: 182:198.
}

A \& C R. de Dir. Administrativo e Constitucional, Belo Horizonte, ano 5, n. 19, p. 11-34, jan./mar. 2005 